${ }^{2}$ Arko, R J, et al, fournal of Infectious Diseases, 1974, 130, 160.

${ }^{3}$ Arko, R J, et al, Infection and Immunity, 1976, 14, 1293.

${ }^{4}$ Watt, P J, Ward, M E, and Glynn, A A, British fournal of Venereal Diseases, 1971, 47, 448.

${ }^{5}$ Glynn, A A, and Ward, M E, Infection and Immunity, 1970, 2, 162.

${ }^{6}$ Johnston, D W, Holmes, K K, and Gotschlich, E C, fournal of Experimental Medicine, 1976, 143, 741.

' Buchanan, T M, and Arko, R J, fournal of Infectious Diseases, 1977, 135, 879

${ }^{8}$ Kellogg, D S, et al, fournal of Bacteriology, 1968, 96, 596.

${ }^{9}$ Novotny, P, Short, J A, and Walker, P D, fournal of Medical Microbiology, $1975,8,413$.

${ }^{10}$ Buchanan, T M, et al, fournal of Clinical Investigation, 1973, 52, 2896.

11 Tramont, E C, Infection and Immunity, 1976, 14, 593.

${ }^{12}$ Buchanan, T M, Fournal of Experimental Medicine, 1975, 141, 1470

${ }^{13}$ Novotny, P, and Turner, W H, fournal of General Microbiology, 1975, 89, 87.

${ }^{14}$ Richardson, W P, and Sadoff, J, Infection and Immunity, 1977, 15, 663.

${ }_{15} \mathrm{James,}$ J F, and Swanson, J, Fournal of Experimental Medicine, 1977, 145, 1082 .

\section{Mortality and oral contraceptives}

Eight years ago both doctors and their patients were taken unawares by an announcement from the Committee on Safety of Drugs ${ }^{1}$ about oral contraceptives and thromboembolism, and there was both public disquiet and professional outrage. We believe that there should be a more considered response to the two papers from Oxford and the Royal College of General Practitioners published this week in the Lancet. ${ }^{23}$ Essentially their findings extend and confirm earlier work, but they put a higher figure on the mortality rate associated with the use of oral contraceptives. On this occasion advance warning was available, and the Royal Colleges of General Practitioners and Obstetricians and Gynaecologists give advice to doctors at $\mathrm{p} 947$.

The first paper presents fresh data from the long-term study of 46000 women organised by the RCGP. The total of womanyears of observation is now about 200000 and there have been 56 deaths in the pill-users and 45 in the controls. Nevertheless, deaths from circulatory disorders (non-rheumatic heart disease, hypertension, and cerebrovascular disorders) were found to be almost five times as common in women on the pill as in those using other contraceptives. The difference in the two death rates is 20 per 100000 women per year, which represents 1 death each year per 5000 women taking the pillsubstantially larger than most previous estimates of this risk. The second paper reports results from another long-term study organised through the Family Planning Association in Oxford. The 17000 women recruited to the trial have been under observation for nine years. So far there have been 43 deaths; but, while there were nine deaths from cardiovascular causes among the women who were taking the pill at the start of the trial, none occurred in those using a diaphragm or an intrauterine device. In both studies, however, the deaths from cardiovascular disease were concentrated in women aged 35 or more, and there was a strong association with smoking. That there is a dramatic change in the risk of pill-associated coronary thrombosis with age and smoking habit was shown by Mann and Inman ${ }^{4}$ in 1975, and these latest results suggest that the same is true of cerebrovascular disorders and of other forms of heart disease.

What are the practical implications of these latest warnings? The Committee on Safety of Medicines (see p 965) and the two Royal Colleges are agreed that there need be no change in oral contraceptive practice for women aged less than 30though they should be warned of the dangers to health of smoking. Surely the reports underline yet again, if it was needed, the importance of firm action by the Government against smoking-in particular, much wider publicity about its dangers. For teenagers and women in their 20 s the pill will remain the first choice for safe, effective contraception. Such a blanket reassurance can no longer be given to women above the age of 30 , and doctors should be prepared to discuss possible alternative forms of fertility control with patients in this age range. Factors which should be taken into account include the length of use of oral contraceptives, cigarette smoking, and general health, including any evidence of diabetes or hypertension."

As the Royal Colleges' statement emphasises, however, there is no need for women in their 30 s and 40 s taking oral contraceptives to make any immediate, panic change. The risks have not increased: they have simply been recalculated-and the total numbers of deaths on which the calculations are based are small. No longer, however, does it seem reasonable to expect women to take oral contraceptives for virtually their whole reproductive span with no thought given to any alternate strategy. The weight that should be given to convenience, reliability, and safety varies with age and with circumstances, and patients need advice and guidance. For many couples who have completed their families sterilisation of either husband or wife may be preferable to any of the other alternatives.

${ }^{1}$ British Medical fournal, 1969, 4, 755.

2 Beral, V, and Kay, C R, Lancet, 8 October 1977.

${ }^{3}$ Vessey, M P, McPherson, K, and Johnson, B, Lancet, 8 October 1977.

${ }^{-}$Mann, J I, and Inman, W H W, British Medical fournal, 1975, 2, 245.

${ }^{5}$ Mann, J I, et al, British Medical fournal, 1975, 2, 241.

\section{Words}

This week we start a new "filler series" in the Medical Practice section, entitled Words. This will be an occasional series browsing among the origins, uses, and curious aspects of medical terminology. For some time this has been one of the hobbies of Dr Bernard Freedman, who has drafted this series, and we hope that readers will enjoy his discoveries about some present-day terms and ancient beliefs. 